\title{
A letter from the past
}

\section{On the dubious position of Aelfus in the evolutionary tree of mankind.}

\section{Ruy José Válka Alves}

Dear Wallace,

On May 11th 1875, while I was at Down House studying whether the strange mathematics Mendel has been sending me affected corollas of Impatiens balsaminea, I fell asleep ... I woke in a snow-clad street and was almost run over by several noisy horseless carriages, driven by angry, vehemently gesticulating people. Two policemen with odd accents arrested me.

At the 'Seattle Police Department' I told them my name was Charles Robert Darwin, of Shrewsbury. They all burst into laughter, and became hostile. I showed them my letter of safe conduct signed by Queen Victoria, which made matters even worse for me: more laughter was followed by them insisting on valid travel documents, visa etc. When I demanded to know what a 'photo' was, he showed me a remarkably small and accurate colour painting of himself. Then he tapped onto some black slab upon his table, which was tied by a string to a quite large black box, from which another string led to a frame with a portrait which flickered and had the most marvellous power of changing its colours (as the Octopus from Sao Tiago). A very old man with a full white beard appeared in the frame. "That was Charles Darwin. You are over a century late!" the chief exclaimed. The image was somewhat familiar, but I am much younger!

As I insisted on my name, the chief accused me of being a lunatic, an illegal alien and a liar. He took a small box out of his pocket, and a flickering elf appeared in it. He spoke intermittently, but I could not hear the elf reply. All around the station, several other policemen were also talking to their own little boxes. And who was the true lunatic?

The only food they brought me that I could identify was a banana, and how a ripe one made its way to this temperate location in midwinter remains quite a mystery. They forced me through a back door into one of the horseless carriages. On the streets, I saw many more people talking to their elves. Soon after we arrived at a 'Mental Institution'.

During several weeks I stayed at that horrible place, but one night someone left a window open so I managed to flee. It was cold and the only open door led me into a public library. Having nowhere to go, I wandered inside and found a considerable collection of books on all subjects, and most importantly, a bit of peace to recover from my previous adventures. Not only did no one bother me at all, but a smiling middleaged lady with thick spectacles even offered me a glass of water (which tasted like

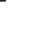

\section{ר}

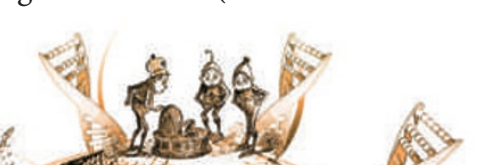

of the origins of Mankind! Searching for a specimen elf in the library, I first broke open one of those small boxes someone had forgotten on the table. Nothing. Then I opened several of the big boxes which had the flickering frames, and searched around with my hand. Something bit me in the hand as a large blue spark charged out of the box. All of a sudden the entire library became pitch dark, and the next minute red torches lit up all by themselves on several walls. The elves must have used this opportunity to escape, as when the white torches lit up again, none were in

sight. Very shortly after that, the police came inside and arrested me again. At the police station, they stuffed parts of the broken boxes into small envelopes made of an incredible material: it was as transparent as clear glass, but more flexible than silk! At first the police chief had not recognized me from the previous incident, but soon after he pressed my thumb against a glowing red box on his table, he exclaimed, with a sarcastic grin: "Aha, Mr 'Daaarwin' again! And this time, you are here for escaping parole, theft and breaking public property!"

In this odd time, there are more creationists everywhere and they even have their own chronicles and institutions; people keep elves in boxes and speak to them in a primitive accent; men of science are judged by where and not what they publish; oh yes, of course: and the potential of horses for transportation has not yet been discovered! Considering these facts, it seems beyond reasonable doubt that I must have travelled backward in time, even though everyone here claims this is the early twenty-first century!

I have failed so far, but I think elves must stand beside modern man at the top of the tree. However, unless I catch a pair once I get out of prison, you shall hear of me no more...

I remain, yrs etc.,

Chas. Darwin.

The author is associate professor at the Botanical Department, National Museum, Federal University of Rio de Janeiro, specializing on oceanic islands and mountain floras.

Join the discussion of Futures in Nature at go.nature.com/QMAm2a 